NBER WORKING PAPER SERIES

\title{
COSTS OF ENVIRONMENTALLY \\ MOTIVATED TAXES IN THE PRESENCE \\ OF OTHER TAXES: GENERAL EQUILIBRIUM ANALYSES
}

\author{
A. Lans Bovenberg
}

Lawrence H. Goulder

Working Paper No. 5117

\section{NATIONAL BUREAU OF ECONOMIC RESEARCH 1050 Massachusetts Avenue \\ Cambridge, MA 02138 \\ May 1995}

We are grateful to Jesse David and Steven Weinberg for excellent research assistance, and to the National Science Foundation (Grant SBR-9310362), IBM Corporation, and Resources for the Future for financial support. This paper is part of NBER's research program in Public Economics. Any opinions expressed are those of the authors and not those of the National Bureau of Economic Research.

() 1995 by A. Lans Bovenberg and Lawrence H. Goulder. All rights reserved. Short sections of text, not to exceed two paragraphs, may be quoted without explicit permission provided that full credit, including $\odot$ notice, is given to the source. 


\title{
COSTS OF ENVIRONMENTALLY \\ MOTTVATED TAXES IN THE PRESENCE OF OTHER TAXES: GENERAL EQUILIBRIUM ANALYSES
}

\begin{abstract}
There has been keen interest in recent years in environmentally motivated or "green" tax reforms. This paper employs analytical and numerical general equilibrium models to investigate the costs of such reforms, concentrating on the question of whether these costs can be eliminated when revenues from new environmental taxes are devoted to cuts in marginal income tax rates. A distinguishing feature of the analytical model is its attention to the role of pre-existing inefficiencies in the tax treatment of labor and capital and the associated role of tax-shifting. This model indicates how the prospects for a zero- or negative-cost environmental tax reform are enhanced to the extent that environmental tax reforms shift the tax burden toward the less efficient (undertaxed) factor.

Results from the numerical model are interpreted in light of the analytical model's findings. These results indicate that the revenue-neutral substitution of Btu or gasoline taxes for typical income taxes usually entails positive gross costs to the economy. In the case of the gasoline tax, a significant tax shifting effect serves to lower the policy's gross costs. This accounts for the lower gross cost of the gasoline tax compared with the Btu tax. Under neither policy is tax-shifting substantial enough to eliminate the overall gross costs.
\end{abstract}

A. Lans Bovenberg

Center for Economic Research

Tilburg University

PO Box 90153

5000 LE Tilburg

THE NETHERLANDS
Lawrence H. Goulder

Department of Economics

Landau Economics Building

Stanford University

Stanford, CA 94305-6072

and NBER 


\section{Introduction}

Interest in taxes as instruments of environmental protection has grown considerably in recent years. In many industrialized countries, environmentally motivated taxes either have recently been introduced or are being seriously discussed as potential elements of future policy initiatives. The actual and potential reforms include taxes on fossil fuels (such as carbon taxes and fossil-based BTU taxes) and taxes on gasoline.

The most important rationale for these taxes is their potential to provide environmental benefits by raising the prices of environmentally damaging activities and thereby reducing the levels of such activities. However, several analysts have pointed out recently that these taxes might confer additional benefits, particularly if the environmental taxes are introduced in a revenue-neutral fashion. A number of authors, including Terkla (1984), Lee and Misiolek (1986), Pearce (1991), Oates (1991), Repetto et al. (1992), Ballard and Medema (1993), and Poterba (1993), have emphasized that the revenues from environmental taxes can be used to finance reductions in the marginal rates of other, distortionary taxes. In this way, an environmental tax reform could help reduce the distortionary costs associated with existing taxes. In this connection, Pearce indicated that environmental taxes might offer a "double dividend:" not only improve the environment but also reduce certain costs of the overall tax system.

The second "dividend" has several possible interpretations. Some policy analysts have endorsed a strong notion, contending that the revenue-neutral swap of environmental taxes for ordinary income taxes involves negative gross costs. ${ }^{1}$ This assertion is equivalent to the claim that whatever gross costs are directly associated with the introduction of an environmental tax are offset entirely by the cost savings stemming from the cuts in ordinary taxes, so that the gross cost of the revenue-neutral tax swap is actually negative. In a world where the magnitudes of the benefits from environmental taxes are highly uncertain, the idea that revenue-neutral environmental taxes involve negative costs is very appealing; for if the costs are negative, one needs to establish only the sign (as opposed to magnitude) of the environmental benefits

\footnotetext{
'The modifier "gross" is employed to indicate that environmental benefits are not netted out. Clearly environmental taxes generally yield both benefits (avoided environmental costs) and costs. This paper concentrates on the cost side of the ledger, in keeping with the focus of discussions of the double dividend.
} 
to be able to justify the tax swap on benefit-cost grounds. The reduction in information requirements is quite attractive, given the substantial uncertainties about benefit magnitudes.

This paper employs both analytical and numerical general equilibrium models to investigate the costs of revenue-neutral environmentally motivated tax reforms. We examine the extent to which the costs of environmental taxes are reduced when the revenues from these taxes are devoted to cuts in marginal income tax rates. Recent analytical work ${ }^{2}$ has shed considerable light on this issue. This work emphasizes that environmental taxes are implicit taxes on factors and that, as a result, the revenue-neutral substitution of an environmental tax for a tax on labor usually does not lead to any actual reduction in labor's tax burden. ${ }^{3}$ Indeed, in these models such a tax swap usually increases labor's tax burden because the environmental tax is less efficient in terms of raising revenue than an explicit labor tax. These considerations militate against the second dividend. The analytical model in this paper departs from earlier models by allowing for two (rather than one) non-polluting primary factors of production -- labor and capital. The generalization is important, since it introduces a channel through which a revenue-neutral tax policy can shift the burden of taxes across the two factors. As analyzed later in the paper, this enhances the prospects for the second dividend.

Despite the substantial interest in the double dividend, there has been relatively little empirical work on the issue, and what has been done tends to lack attention to the underlying mechanisms that drive the results. In this paper, results from the numerical model are interpreted in light of the mechanisms identified by the analytical model. The numerical model's results weigh against the double dividend. Under a range of specifications for revenue-replacement methods, pre-existing tax rates, and parameter values, the revenue-neutral substitution of environmentally motivated taxes for typical income taxes entails positive gross costs to the economy. This result obtains despite the fact that, in some simulations, $\operatorname{tax}$ shifting works in favor of a second dividend. We find that, under plausible parameter specifications, the

\footnotetext{
${ }^{2}$ See, for example, Bovenberg and de Mooij (1994), Bovenberg and van der Ploeg (1994), Parry (1994), Goulder (1995a), and Oates (1995).

${ }^{3}$ The idea that intermediate taxes and commodity taxes are implicit factor taxes is not new. It is implicit, for example, in Diamond and Mirrlees (1971). However, this notion was often overlooked in initial discussions of the double dividend.
} 
tax shifting effect cannot overcome the so-called tax burden effect, that is, the adverse cost impact associated with the relatively narrow bases of environmental taxes.

The rest of the paper is organized as follows. Section II presents the analytical model and its results. Section III describes the numerical model, while Section IV presents its results. The final section offers conclusions.

\section{Costs of Revenue-Neutral Environmental Tax Reforms: Analytical Results}

\section{A. The Model}

Here we develop a simple model of an economy in which firms maximize profits under perfect competition. Production is described by a constant-returns-to-scale CES production function $F(L, K, R)$ with a constant elasticity of substitution of $\sigma$. In contrast with earlier analytical models of the double dividend issue (see Bovenberg and de Mooij (1994)), two (rather than one) primary non-polluting production factors enter production: namely, labor $(L)$, and (clean) capital $(K)$. The "polluting resource," $R$, harms environmental quality: $E=e(R)$, with $e_{R}<0$, where the subscript denotes a partial derivative. $R$ can be interpreted as the use of fossil fuels in production. ${ }^{4}$

The representative household maximizes utility $u[m(C, 1-L), G, E] .^{5}$ The composite $m$ of private consumption $(C)$ and leisure $(l-L)$ is homothetic and weakly separable from public goods $G$ and $E$, which denote public consumption and environmental quality. The household budget constraint is:

$$
C=w L+p_{\mathrm{K}} \bar{K}+p_{R} \bar{R}
$$

where $\bar{K}$ and $\bar{R}$ stand for the domestic endowments of (clean) capital and the polluting resource. We

\footnotetext{
4 Alternatively, it can be regarded as manufactured capital that generates pollution when it is employed in production. Under either interpretation, production technologies are cleaner to the extent that they rely more on $K$ and less on $R$.

${ }^{5}$ The number of hours available for work has been normalized at unity.
} 
regard the economy as small and open. Whereas labor is immobile, capital and the polluting resource are mobile internationally. Hence, while the consumer wage, $w$, is endogenous, the required return on the world capital market $p_{R}$ and the world market price of the polluting resource $p_{R}$ are exogenous. ${ }^{6}$

The govemment budget constraint amounts to:

$$
G=t_{K} p_{K} K+t_{R} p_{R} R+t_{L} w L
$$

where $t_{L}, t_{K}$, and $t_{R}$ stand for the tax rates on labor, capital, and the polluting input, respectively. We assume (without loss of generality) that the consumption commodity is untaxed. Equilibrium on the balance of payments is given by:

$$
F(L, K, R)=G+p_{K}(K-\bar{K})+p_{R}(R-\bar{R})+C
$$

The welfare effects of a revenue-neutral change in the tax mix (i.e., a change in taxes such that $d G=0$ ) are given by (see Appendix A):

$$
\frac{d u}{u_{C}}=-\frac{u_{E}}{u_{C}}\left[\left(-e_{R}\right) d R\right]+[L d w]
$$

where subscripts denote partial derivatives with respect to a particular variable. The first term at the righthand side of equation (4) is the first, environmental, dividend: that is, the welfare effect of changes in environmental quality. The second term, which is the change in real (after-tax wage) income enjoyed by households, represents the second, non-environmental (or private), dividend. A positive second dividend implies that overall tax burden declines. Hence, the gross ${ }^{7}$ costs of attaining higher environmental quality are negative.

We now analyze an environmental tax reform in which the govemment raises the tax on the

'The assumed exogeneity of $p_{\mathrm{K}}$ and $p_{\mathrm{R}}$ simplifies the analysis. However, as discussed in subsection $\mathrm{D}$ below, the main channels exposed by this model also apply if supplies of $K$ and $R$ are less than infinitely elastic.

7 As mentioned in the introduction, the modifier "gross" indicates that environmental benefits are not netted out. 
polluting resource and uses the revenues to cut distortionary taxes on either labor or capital, while keeping government consumption fixed. In the case where the revenues from the environmental tax are employed to cut the tax on capital income, the solutions for private welfare (i.e., consumer wages), resource demand (which is inversely related to environmental quality), and capital demand are (see Appendix B) ${ }^{8}$ :

$$
\begin{gathered}
\tilde{w}=\left(\theta_{\mathrm{K}}-\theta_{R}\right) \omega_{R} \frac{\sigma}{\Delta_{\mathrm{K}}} \tilde{t}_{R} \\
\tilde{R}=\left[-1+\left(\theta_{\mathrm{K}}-\theta_{R}\right) \omega_{R} \frac{\eta_{L}+\sigma}{\Delta_{\mathrm{K}}}\right] \sigma \bar{t}_{R} \\
\tilde{K}=\left[1+\left(\theta_{\mathrm{K}}-\theta_{R}\right) \frac{\eta_{L} \omega_{\mathrm{K}}+\sigma\left(1-\omega_{R}\right)}{\Delta_{\mathrm{K}}}\right] \sigma \frac{\omega_{R}}{\omega_{\mathrm{K}}} \tilde{t}_{R}
\end{gathered}
$$

where $\Delta_{K} \equiv\left(1-\theta_{L}\right) \omega_{L}-\eta_{L}\left(\theta_{L} \omega_{L}+\theta_{R} \omega_{R}+\theta_{K} \omega_{R}\right)-\left(\theta_{R} \omega_{R}+\theta_{K}\left(1-\omega_{R}\right)\right) \sigma>0$, and $\tilde{t}_{i}=d t_{i} /\left(1+t_{i}\right), i=L, K, R$. For non-tax variables, a tilde stands for a relative change. $\eta_{L}$ represents the uncompensated wage elasticity of labor supply, while $\omega_{i}$ and $\theta_{i}$ respectively correspond to the production share of input $i(i=L, K, R)$ and the tax rate as percentage of the before-tax price (i.e., $\theta_{i} \equiv t_{i} /\left(1+t_{i}\right)$ ).

The corresponding solutions for the case in which labor rather than capital taxes are cut amount to (see Appendix B):

$$
\begin{gathered}
\bar{w}=-\left[\theta_{\mathrm{K}} \omega_{\mathrm{K}}+\theta_{R}\left(1-\omega_{\mathrm{K}}\right)\right] \frac{\omega_{R}}{\omega_{L}} \tilde{t}_{R} \\
\bar{R}=-\left[\left(1-\omega_{R}\right)+\left(\theta_{\mathrm{K}} \omega_{\mathrm{K}}+\theta_{R}\left(1-\omega_{\mathrm{K}}\right)\right) \frac{\omega_{R} \eta_{L}}{\Delta_{L}}\right] \frac{1}{\omega_{L}} \sigma \tilde{t}_{R} \\
\bar{K}=-\left[1+\left(\theta_{K} \omega_{K}+\theta_{R}\left(1-\omega_{K}\right)\right) \frac{\eta_{L}}{\Delta_{L}}\right] \frac{\omega_{R}}{\omega_{L}} \sigma \bar{t}_{R}
\end{gathered}
$$

where $\Delta_{L} \equiv\left(1-\theta_{L}\right) \omega_{L}-\eta_{L}\left[\theta_{L} \omega_{L}+\theta_{R} \omega_{R}+\theta_{K} \omega_{K}\right]>0$

\footnotetext{
${ }^{8}$ The solutions are derived from a log-linearized model. Hence they hold only for marginal changes in taxes.
} 


\section{B. Environmental Taxation in an Optimal Tax System}

First, we explore the impact of environmental taxes if the initial tax system is optimal from a nonenvironmental point of view. Such a tax system involves only labor taxes because pollution and capital taxes are "inefficient"9 instruments for raising revenues. Intuitively, just like a labor tax, pollution and capital taxes are shifted to labor in the form of lower real wages because the supplies of the polluting resource and capital to the economy are infinitely elastic. Hence it is less costly to impose the labor tax, which distorts only the labor market, than the resource or capital taxes, which distort not only the labor market (to the same or greater degree) but also the resource and capital markets by changing the relative prices of the resource and capital.

Introducing a small pollution tax in this setting produces no first-order impacts on private welfare. To see this, note from expressions (5) and (8) that $w$ is zero when $\theta_{\mathrm{K}}=\theta_{R}=0$. This result follows also from the definition of the initial optimum. If the incremental revenue-neutral substitution of taxes altered non-environmental welfare, such welfare could be increased by changing the levels of taxes. This would contradict the notion that the initial situation was optimal from a non-environmental point of view.

To examine the welfare effects of large pollution levies, we turn to the case in which the environmental (resource) tax is positive in the initial equilibrium (but the tax on capital is still zero). With a positive initial pollution tax, the environmental dividend comes at the cost of a negative non-environmental (or second) dividend. This can be seen by substituting $\theta_{K}=0$ and $\theta_{R}>0$ into expressions (5) and (6) for a cut in capital taxes and into expressions (8) and (9) for a cut in labor taxes. The intuition behind the negative private dividend was suggested two paragraphs above: from a non-environmental point of view, pollution taxes are less "efficient" than explicit labor taxes. Pollution taxes thus raise the overall tax burden, as measured by the drop in private incomes. This is called the tax burden effect (see Bovenberg (1995)). Indeed, equations (5) and (8) indicate that the higher the initial levels of pollution taxes (that is, the higher is $\theta_{\mathrm{R}}$ ), the larger are the marginal costs of pollution taxes in terms of the burden on private incomes. Of course, higher pollution taxes also raise the supply of environmental quality, a

\footnotetext{
9 We place the words "inefficient" and "efficient" in quotes to acknowledge the fact that we are abstracting from efficiency issues associated with environmental quality. A tax that is relatively inefficient when the environmental dimension is ignored may well be relatively efficient once the environmental dimension is considered.
} 
public good, and the benefits from this public good may justify the higher tax burden. However, this does not deny the notion an environmental tax reform imposes costs in terms of private incomes -- which is the issue at the heart of the double dividend debate.

\section{Environmental Taxation in a Suboptimal Tax System}

We now investigate the welfare effects in a setting where the initial tax system is not optimal from a non-environmental point of view. We will see that the suboptimality of the tax system yields another channel through which environmental taxes influence private welfare and introduces the possibility of a positive non-environmental dividend. In this new setting, capital (as well as labor) taxes are positive in the initial equilibrium. Thus, from an efficiency point of view (abstracting from the environmental dimension), capital taxes are too high. ${ }^{10}$ With positive capital taxes and zero pollution taxes in the initial equilibrium, private welfare increases if and only if the demand for capital increases (substitute $\theta_{R}=0$ and $\theta_{K}>0$ into expressions (5) and (7) for a cut in capital taxes and expressions (8) and (10) for a cut in labor taxes). Intuitively, capital is "overtaxed" in the initial equilibrium and therefore yields a higher before-tax value marginal product per dollar than does labor. Hence, if a revenue-neutral environmental reform were to cause an increase in the supply of the more efficient factor, private welfare would rise. To determine whether this occurs, we must specify which taxes are reduced in exchange for the increase in the pollution tax.

\section{Lowering Capital Taxes}

If the pollution tax finances a cut in capital taxes, capital demand expands, which tends to raise private welfare (see expressions (5) and (7) with $\theta_{R}=0$ ). Intuitively, the tax that is reduced directly stimulates capital demand, while the tax that is raised (i.e. the environmental tax) does not bear directly on capital but also affects labor demand. Thus, while the capital tax directly impacts the capital market, the burden of the environmental tax is spread over both the capital and labor markets. Hence, the revenue-

\footnotetext{
${ }^{10}$ There may be political economy (or distributional) reasons why the initial tax system is not optimal. The analysis in this section is closely related to the literature on tax reform, which explores the possibility of moving to a more efficient tax system starting from suboptimal systems.
} 
neutral reform package shifts the burden away from the efficient factor (capital) to the inefficient factor (labor). This makes the tax system more efficient from a non-environmental point of view.

The reallocation of the tax burden between the efficient and the inefficient factor will be called the tax shifting effect. This effect is positive if it redistributes the burden of taxation away from the overtaxed to the undertaxed factor. ${ }^{11}$ With zero initial pollution taxes, a positive tax shifting effect is a sufficient condition for a double dividend.

With positive resource taxes in the initial equilibrium, private welfare expands if and only if the tax shifting effect dominates the tax burden effect so that the efficiency gains associated with the shift in the tax burden away from the overtaxed factor are sufficiently large to offset other gross costs from the environmental tax. This means that the environmental tax reform yields a positive effect on private (nonenvironmental) welfare if and only if it moves the overall tax system closer to its non-environmental optimum.

\section{Lowering Labor Taxes}

If the govemment cuts labor rather than capital taxes, the introduction of pollution taxes reduces private welfare (see expression (8) with $\theta_{R}=0$ ). Here both the tax shifting effect and the tax burden effect harm non-environmental welfare. In contrast with the case where capital taxes were lowered, in this case the tax shifting effect reduces private welfare. This occurs because the tax burden is shifted the "wrong" way -- from the inefficient factor (labor) to the efficient factor (capital). Whereas only the labor market is affected directly by the tax that is cut (i.e. the labor tax), the capital market bears part of the burden of the environmental tax. Hence the overall effect of the revenue-neutral reform is to shift the burden from labor to capital.

\footnotetext{
"In our analytical model, labor bears the ultimate burden of all taxes in terms of reduced real incomes because the supply of capital is infinitely elastic. Thus, the burden of taxation on the capital market is reflected only in a decline of the capital demand and not in a drop in the after-tax retum on capital. The burden in terms of reduced incomes is shifted back onto labor. In a more general model in which capital supply is less than infinitely elastic, the burden of taxation in the capital market would reduce not only capital demand but also the after-tax rate of return on capital. In this case, labor and capital would share the burden of taxation in terms of lower after-tax incomes. See also section $\mathrm{D}$ below.
} 


\section{Observations and Caveats}

The analytical model presented shows that when the initial tax system is optimal from a nonenvironmental point of view, the second, non-environmental dividend fails to materialize. This accords with results of simpler models (see Bovenberg and de Mooij [1994]). By introducing a second clean input in the present model, we have been able to consider an initial situation in which the relative taxation of clean factors (capital and labor) is not optimal. In such situations, a tax shifting effect accompanies the tax burden effect. Tax shifting can either lower or raise the attractiveness of revenue-neutral environmental tax reforms: it can shift the burden toward already overtaxed factors and thereby exacerbate inefficiencies in the tax system, or it can shift the burden the other way and thereby help alleviate initial inefficiencies. In the latter case, the double dividend becomes a possibility. These theoretical results indicate that the presence or absence of the double dividend must be settled empirically, as it depends on initial conditions, the incidence of the pollution tax, and the way that environmental tax revenues are "recycled" to the economy.

To keep the analytical model tractable, we have imposed a number of simplifying assumptions, and some caveats are in order. First, we treated supplies of capital and the polluting resource as perfectly elastic, in keeping with the assumption of a small, open economy. The assumption that capital is perfectly elastically supplied underlies the idea that capital is initially overtaxed. If capital supply is less than perfectly elastic, labor can be the overtaxed factor initially, depending on elasticities of factor supply and demand and on the tax rates. If labor is initially overtaxed, the analytical results are reversed, although the economic logic remains the same. In this situation, the revenue-neutral substitution of an environmental tax for another tax produces a beneficial tax shifting effect (and could generate a double dividend) to the extent that it helps shift the burden away from labor. Bovenberg and van der Ploeg (1995) analyze this issue in a model in which capital is supplied perfectly inelastically. Their results complement those derived above in reinforcing the notion that the nature of the initial inefficiency (which factor is overtaxed) and the direction of tax shifting are key channels for assessing the double dividend.

The analytical model also abstracted from complications such as sectoral disaggregation, intermediate inputs, and dynamics. The numerical model incorporates these features. We find that the 
key features identified by the simpler analytical model -- the tax shifting and tax burden effects -- can largely explain the effects of revenue-neutral environmental tax reforms in the more complex numerical model.

\section{Basic Features of the Numerical Model}

This section sketches out the main features of the numerical model. Some details on the model's structure and parameters are offered in Appendix C. A more complete description is contained in Goulder (1992). Cruz and Goulder (1992) provide data documentation.

The model is an intertemporal general equilibrium model of the U.S. economy with international trade. It generates paths of equilibrium prices, outputs, and incomes for the U.S. economy and the "rest of the world" under specified policy scenarios. All variables are calculated at yearly intervals beginning in the 1990 benchmark year and usually extending to the year 2070 .

The model is unique in combining a fairly realistic treatment of the U.S. tax system and a detailed representation of energy production and demand. It incorporates quite specific tax instruments and addresses effects of taxation along a number of important dimensions; these include firms' investment incentives, equity values, and profits, ${ }^{12}$ and household consumption, saving and labor supply decisions. The specification of energy supply incorporates the nonrenewable nature of crude petroleum and natural gas and the transitions from conventional to synthetic fuels.

\section{A. Industry and Consumer Good Disaggregation}

U.S. production divides into the 13 industries indicated in Table 1. The energy industries consist of coal mining, crude petroleum and natural gas extraction, petroleum refining, synthetic fuels, electric utilities, and gas utilities. The model distinguishes the 17 consumer goods in Table 1.

\footnotetext{
${ }^{12}$ Here the model applies the asset price approach to investment developed in Summers (1981).
} 


\section{B. Producer Behavior}

\section{General Specifications}

In each industry, a nested production structure accounts for substitution between different forms of energy as well as between energy and other inputs. Each industry produces a distinct output $(X)$, which is a function of the inputs of labor $(L)$, capital $(K)$, an energy composite $(E)$ and a materials composite $(M)$, as well as the current level of investment (I):

$$
X=f(g(L, K), h(E, M)]-\phi(I / K) \cdot I
$$

The energy composite is made up of the outputs of the six energy industries, while the materials composite consists of the outputs of the other industries:

$$
\begin{gathered}
E=E\left(\bar{x}_{2}, \bar{x}_{3}+\bar{x}_{4}, \bar{x}_{5}, \bar{x}_{6}, \bar{x}_{7}\right) \\
M=M\left(\bar{x}_{1}, \bar{x}_{8}, \ldots, \bar{x}_{13}\right)
\end{gathered}
$$

where $\bar{x}_{i}$ is a composite of domestically produced and foreign made input $i^{13}$ Industry indices correspond to those in Table 1.

Managers of firms choose input quantities and investment levels to maximize the value of the firm. The investment decision takes account of the adjustment (or installation) costs represented by $\phi(I / K) \cdot I$ in equation (10). $\phi$ is a convex function of the rate of investment, $/ / K^{14}$

\section{Special Features of the Oil-Gas and Synfuels Industries}

The production structure in the oil and gas industry is somewhat more complex than in other industries to account for the nonrenewable nature of oil and gas stocks. The production specification is:

$$
X=\gamma(Z) \cdot f[g(L, K), h(E, M)]-\phi(I / K) \cdot I
$$

where $\gamma$ is a decreasing function of $Z$, the amount of cumulative extraction of oil and gas up to the

${ }^{13}$ The functions $f, g$, and $h$, and the aggregation functions for the composites $E, M$, and $\bar{x}_{i}$, are CES and exhibit constant returns to scale. Consumer goods are produced by combining outputs from the 13 industries in fixed proportions.

${ }^{14} \phi$ represents adjustment costs per unit of investment. This function expresses the notion that installing new capital necessitates a loss of current output, as existing inputs $(K, L, E$ and $M)$ are diverted to install new capital. 
beginning of the current period. This captures the idea that as $Z$ rises (or, equivalently, as reserves are depleted), it becomes increasingly difficult to extract oil and gas resources, so that greater quantities of $K, L, E$, and $M$ are required to achieve any given level of extraction (output). Increasing production costs ultimately induce oil and gas producers to remove their capital from this industry. ${ }^{15}$

The model incorporates a synthetic fuel -- shale oil -- as a backstop resource, a perfect substitute for oil and gas. The technology for producing synthetic fuels on a commercial scale is assumed to become known in 2010. Thus, capital formation in the synfuels industry cannot begin until that year.

All domestic prices in the model are endogenous, except for the domestic price of oil and gas. ${ }^{16}$ The path of oil and gas prices follows the assumptions of the Stanford Energy Modeling Forum. ${ }^{17}$ The supply of imported oil and gas is taken to be perfectly elastic at the world price. So long as imports are the marginal source of supply to the domestic economy, domestic producers of oil and gas receive the world price (adjusted for tariffs or taxes) for their own output. However, rising oil and gas prices stimulate investment in synfuels. Eventually, synfuels production plus domestic oil and gas supply together satisfy all of domestic demand. Synfuels then become the marginal source of supply, so that the cost of synfuels production rather than the world oil price dictates the domestic price of fuels. ${ }^{18}$

\section{Household Behavior}

Consumption, labor supply, and saving result from the decisions of a representative household maximizing its intertemporal utility, defined on leisure and overall consumption in each period. The utility function is homothetic and leisure and consumption are weakly separable (see Appendix C). The

\footnotetext{
${ }^{15}$ The attention to resource stock effects distinguishes this model from other disaggregated general equilibrium energy environmental models. Many equilibrium models treat the domestic oil \& gas industry as involving constant-retums-toscale production, disregarding resource stock effects or fixed factors. In their global energy-environment model, Manne and Richels (1992) impose stock limits on resources such as oil and gas; however, these limits to do not affect production costs prior to the point where the resource is exhausted. (11).

${ }^{16}$ Thus, inputs 3 (oil\&gas) and 4 (synfuels) enter additively in the energy aggregation function shown in equation

${ }^{17}$ The world price is $\$ 24$ per barrel in 1990 and rises in real terms by $\$ 6.50$ per decade. See Gaskins and Weyant (1994).

${ }^{18}$ For details, see Goulder (1994, 1995b).
} 
household faces an intertemporal budget constraint requiring that the present value of consumption not exceed potential total wealth (nonhuman wealth plus the present value of labor and transfer income). In each period, overall consumption of goods and services is allocated across the 17 specific categories of consumption goods or services shown in Table 1. Each of the 17 consumption goods or services is a composite of a domestically and foreign-produced consumption good (or service) of that type. Households substitute between domestic and foreign goods to minimize the cost of obtaining a given composite.

\section{The Government Sector}

The government collects taxes, distributes transfers, and purchases goods and services (outputs of the 13 industries). The tax instruments include energy taxes, output taxes, the corporate income tax, property taxes, sales taxes, and taxes on individual labor and capital income. In the benchmark year, 1990, the government deficit amounts to approximately two percent of GNP. In the reference case (or status quo) simulation, the real deficit grows at the steady-state growth rate given by the growth of potential labor services. In the policy-change cases, we require that real government spending and the real deficit follow the same paths as in the reference case. To make the policy changes revenue-neutral, we accompany the tax rate increases that define the various policies with reductions in other net taxes, either on a lump-sum basis (increased exogenous transfers) or through reductions in marginal tax rates.

\section{E. Foreign Trade}

Except for oil and gas imports, imported intermediate and consumer goods are imperfect substitutes for their domestic counterparts. ${ }^{19}$ Import prices are exogenous in foreign currency, but the domestic-currency price changes with variations in the exchange rate. Export demands are modeled as functions of the foreign price of U.S. exports and the level of foreign income (in foreign currency). The exchange rate adjusts to balance trade in every period.

\footnotetext{
${ }^{19}$ Thus, we adopt the assumption of Armington (1969).
} 


\section{F. Equilibrium and Growth}

The solution of the model is a general equilibrium in which supplies and demands balance in all markets at each period of time. The requirements of the general equilibrium are that supply equal demand for labor inputs and for all produced goods ${ }^{20}$, that firms' demands for loanable funds match the aggregate supply by households, and that the govemment's tax revenues equal its spending less the current deficit. These conditions are met through adjustments in output prices, in the market interest rate, and in lump-sum taxes or marginal tax rates. ${ }^{21}$

Economic growth reflects the growth of capital stocks and of potential labor resources. The growth of capital stocks stems from endogenous saving and investment behavior. Potential labor resources are specified as increasing at an exogenous rate. ${ }^{22}$

\section{Results from the Numerical Model}

Here we present the numerical model's assessment of the costs of environmentally motivated taxes in the presence of distortionary taxes. We concentrate on the gross efficiency costs of environmentally motivated taxes relative to "traditional" income taxes of equal revenue yield. This issue underlies the question whether the revenue-neutral substitution of an environmental tax for an existing traditional tax implies gross costs overall.

\section{A. Policies Considered}

We examine the following four policies:

1. A Btu tax. This is a tax imposed on oil, natural gas, and coal in proportion to the Btu content of these fuels. The tax rate is $\mathbf{0 . 4 5}$ per million Btu's. The same tax rates apply to imported fuels as to the domestically produced counterparts. Exports of fuels are exempt from the tax.

\footnotetext{
${ }^{20}$ Since oil and gas synfuels are perfect substitutes, they generate a single supply-demand condition.

${ }^{21}$ Since agents are forward-looking, equilibrium in each period depends not only on current prices and taxes but on future magnitudes as well.

${ }^{22}$ Since oil and gas synfuels are perfect substitutes, they generate a single supply-demand condition.
} 
2. An increase in the gasoline tax. This is a specific, or per-unit tax on the purchases of gasoline by consumers. "Gasoline and other fuels" is one of the 17 consumer goods distinguished in the model. The gasoline tax applies to household purchases of this good. This tax is increased to 0.692 per gallon from its original or benchmark value of 0.287 per gallon.

3. An increase in marginal rates of the personal income tax. The model includes marginal tax rates on individual wage income, dividend income, interest income, and capital gains income. These are the average marginal rates that apply in the benchmark year, 1994. The benchmark marginal rates on wage income, dividend income, interest income, and capital gains income are $.230, .229, .229$, and .057 , respectively. Under this policy change, each of these rates is increased by 1.9 percent.

4. An increase in the corporate income tax rate. Here the marginal rate on corporate profits is increased to .399 from its initial value of .385 .

The first two policies fall in the category of envimnmentally motivated taxes. These are taxes on fuels rather than direct taxes on emissions. Other things equal, emissions taxes are preferable to fuels taxes as means of correcting externalities associated with emissions; in practice, however, monitoring and enforcement difficulties have tended to limit the use of emissions taxes.

To assess the effects of these taxes, we compare results under each simulated policy change with results from a baseline or reference case simulation (which assumes no change in tax policy). In the baseline simulation, all tax rates remain constant through time. All policies changes phase in the new tax rates over a three-year period, beginning in 1994.

Each policy is introduced in a revenue-neutral fashion: the path of tax revenues under each policy is made identical to the revenue path in the baseline. Revenue-neutrality is achieved either through lump-sum reductions in personal income taxes or through reductions in the marginal tax rates on individual income.

For comparability, the tax changes under each policy are scaled to imply the same gross revenue impact -- the same revenue yield, abstracting from the revenue-preserving reductions in other taxes. The gross revenue impact of these policies, over the infinite time horizon, is $\$ 1084$ billion in present value. Over the first five years, these taxes yield gross revenues ranging from 55 to 69 billion 1990 dollars. 


\section{B. Simulation Results}

\section{Differences in Aggregate Economic Impacts}

We begin by examining policies involving lump-sum replacement of revenues. Figures 1a-1c show the effects of the alternative policies on real GNP, consumption, and investment. The figures indicate the percentage change in these variables relative to a reference case involving no policy change. The first year corresponds to 1994.

Figure 1a compares the GNP effects. Within the first 9 years following implementation, the Btu and gasoline taxes imply larger reductions in GNP than the income tax altematives. For example, in the year 2000 (five years after implementation), the Btu and gas taxes entail GNP reductions (relative to baseline) of about .21 and .18 percent, as compared with .15 and .08 percent under the personal and corporate tax increases. The GNP costs of the Btu tax remain larger than those of the income tax alternatives. In contrast, the GNP costs of the gasoline tax eventually become smaller than that of the personal tax increase. The relatively benign long-term GNP impact of the gasoline tax reflects its more favorable impact on investment, as discussed below.

The impacts on consumption are compared in Figure 1b. As with the GNP losses, the losses in consumption are greatest for the energy tax policies. However, in contrast with the GNP results, the losses here are greater for the gasoline tax than the Btu tax. While the Btu tax raises the costs of production for intermediate, capital, and consumer goods, the gasoline tax targets only consumption. Thus, in comparison with the Btu tax, the gasoline tax yields GNP losses more in the form of reduced consumption rather than reduced investment.

Figure 1c contrasts the investment impacts. The investment losses of the gasoline tax are less severe than those of any of the other policies. Hence the path of the capital stock is higher under the gasoline tax than under the other policies. This helps explain why, over time, the GNP path under the gasoline tax improves relative to the paths under the other policies.

Another way to examine the relative costs of the environmental and income taxes is to simulate policies in which an environmental tax replaces (at the margin) an income tax in a revenue-neutral fashion. Figures $2 \mathrm{a}-2 \mathrm{c}$ show results from such simulations. The simulations involve the same tax increases as 
above for the Btu, gasoline, and corporate taxes, but here the tax revenues are used to finance reductions in marginal rates of the personal income tax rather than lump-sum tax reductions. By comparing the results in figures 2a-2c with those of figures 1a-1c, one can observe that the effects from the new simulations involving personal income tax cuts are approximately the same as what one would get if one subtracted the effects of the personal income tax in figures $1 \mathrm{a}-1 \mathrm{c}$ from the effects of the relevant other tax in those figures. The impacts of the component tax changes are close to additive.

We assess the aggregate (gross) welfare impact from these policies by employing the equivalent variation measure, which translates changes in utility from a given policy into a dollar equivalent. ${ }^{23}$ Table 2 displays the welfare costs per dollar of revenue raised, for each of the four policies.

Table 2's results for policies with lump-sum replacement indicate that the environmentally motivated taxes involve larger welfare costs than the income tax alternatives. Correspondingly, the results with replacement through personal income tax cuts indicate that a revenue-neutral swap of an environmental tax for a (marginal) reduction in the personal income tax involves costs overall: the environmental taxes fail to generate a second (double) dividend.

With lump-sum replacement, the cost of the personal income tax is about 57 percent of the cost of the Btu tax and 63 percent of the cost of the gasoline tax. Correspondingly, when the energy taxes are combined with revenue-preserving cuts in the income tax, welfare costs fall by about 40 percent relative to the case with lump-sum revenue replacement. ${ }^{24}$ The Btu tax involves the highest welfare cost per dollar of revenue.

\section{Explaining the "Excess Costs" of Environmental Taxes}

A main result from these experiments is that the environmentally motivated taxes generate larger gross costs per dollar than income taxes. To what can these "excess costs" be attributed? The excess

\footnotetext{
${ }^{23}$ Specifically, the equivalent variation is the increment to initial wealth which, given the prices and policy environment of the reference case, would enable the household to enjoy the same level of utility as under the policy change. A positive equivalent variation thus implies that the policy change is welfare-improving.

${ }^{24}$ For example, in Table 2 the cost of the Btu tax falls from .656 per dollar under lump-sum replacement to .396 per dollar under personal tax replacement.
} 
costs are consistent with analytical results by Bovenberg and de Mooij (1994) and Bovenberg and van der Ploeg (1994); these studies show that environmentally motivated taxes are implicit factor taxes that introduce comparable factor market distortions to those of income taxes while introducing additional distortions in intermediate input choice (Btu tax) or consumer good choice (gasoline tax).

The analytical model of the present paper introduced a further consideration, however: it showed that if initially the tax system is inefficient from a non-environmental point of view, the excess costs of an environmental tax may be reduced or even eliminated if the environmental tax poses a larger burden on the relatively inefficient (or relatively lightly taxed) factor than the tax it replaces. Equivalently, the costs of a revenue-neutral environmental tax reform are reduced to the extent that such substitution manages to shift the tax burden away from the highly taxed (efficient) factor. The costs of the revenueneutral policy may even be negative: the double dividend is a possibility.

In the numerical model, labor is relatively lightly taxed in the sense that the marginal excess burden (MEB) per dollar of revenue raised is higher for the capital income tax than for the labor tax. In particular, under central case values for parameters the MEB is $\$ 0.43$ for the capital income tax, and $\$ 0.31$ for the labor income tax. Most numerical studies of the relative efficiency costs of labor and capital taxes in the U.S. economy obtain the same qualitative result. ${ }^{25}$ This means that environmental taxes that fall heavily on labor (relative to the income tax) may have relatively low excess costs.

This information helps to explain the differences in the excess costs of the Btu and gasoline taxes. Table 3 shows the factor tax burden of the Btu, gasoline, and personal taxes, "alone" (that is, with lumpsum replacement of revenues) and in combination. The table also displays associated effects on equilibrium factor supplies. As indicated by effects on the returns to labor and capital, the burden of the gasoline tax falls primarily on labor, ${ }^{26}$ while that of the Btu tax is shared more evenly by capital and labor. When the gasoline tax is used to finance reductions in the personal income tax, the real wage falls

\footnotetext{
${ }^{25}$ See, for example, Ballard, Shoven, and Whalley (1985).

${ }^{26}$ The gasoline tax is effectively a narrow-based consumption tax. As such, its burden falls primarily on labor and existing (old) capital. For a discussion of the incidence of consumption taxes see, for example, Auerbach and Kotlikoff (1987). Swapping the gasoline tax for existing income taxes reduces the tax burden on new investments (or new capital), as indicated by Table 3 and the investment paths in figures 1 and 2 .
} 
between .3 and .7 percent, and the real returm to capital increases from about .1 to .2 percent; in contrast, substituting the Btu tax for the income tax leads to less pronounced declines in the real wage and to reductions in the real retum to capital. Thus, in an economy where labor is initially taxed relatively lightly, the gasoline tax reform leads to tax shifting that mitigates its excess costs. In contrast, the Btu tax reform yields relatively little tax shifting. This helps explain why the gasoline tax involves lower excess costs per dollar than the Btu tax. Our results are qualitatively similar to those obtained by Rotemberg and Woodford (1994) in a more aggregated model that addresses issues of imperfect competition. These authors find that the costs of energy taxes are considerably smaller when the taxes are imposed at the household level only (as with the gasoline tax here), as compared with the case where taxes are imposed on all energy (as with the Btu tax).

Theory also predicts that the excess costs of environmental taxes (i.e., the tax burden effect from Section II) are related to the breadth of the tax base. The broader the base of these taxes, the smaller the distortions introduced in intermediate input choice or in consumer good choice, and thus the lower the excess cost or tax burden effect. To test this prediction, we perform two additional simulations. First, we simulate a uniform, broad-based tax on intermediate inputs with the same gross revenue impact as the taxes already considered. Since the Btu tax is also a tax on intermediate inputs (of oil, natural gas, and coal), the main structural difference between the broad-based tax and the Btu tax is the breadth of base. Second, we simulate a uniform, broad-based consumption tax -- applying to all consumer goods, not just consumer purchases of gasoline. This isolates the significance of the breadth of the tax base at the level of household consumption. Because these taxes are broad, they clearly would not be effective as instruments of environmental policy. We consider them now only to identify the significance of the breadth of the tax base.

Table 4 compares the excess costs of the narrow and broad taxes. The excess costs of the broadbased intermediate input tax are only a third as large as the excess costs of the Btu tax. Moreover, the excess costs of the broad-based consumption tax are negative: the consumption tax involves lower gross costs than the income tax. This is in keeping with the consumption tax's shifting of the tax burden onto (lightly taxed) labor. In contrast with the case of the gasoline tax, under the broad-based consumption 
tax policy, tax shifting does not have to offset the tax burden effect, that is, excess costs associated with distortions in consumer good choice. Hence it yields negative excess costs.

Thus the numerical results support the predictions from the analytical model. Both the Btu and gasoline tax produce excess costs relative to the income tax as a result of distortions in intermediate input choice (Btu tax) and consumer good choice (gasoline tax). In the case of the gasoline tax, tax shifting mitigates, but does not eliminate, the excess costs. Broader tax bases reduce the intermediate input or consumer good distortions and imply lower excess costs.

It is important to keep in mind that we abstract entirely from the (environmental) benefits from environmentally motivated taxes. The presence of excess costs (or, equivalently, the absence of the double dividend) does not eliminate the efficiency case for such taxes. But it does mean that environmental benefits must be invoked to make this case.

\section{Sensitivity Analysis}

Table 5 shows the sensitivity of results to key parameters. The first three columns show the welfare costs per dollar for the Btu, gasoline, and personal income tax, when revenues are retumed lumpsum. The last two columns contain the excess costs of the Btu or gasoline tax relative to the personal income tax.

Higher values for labor-leisure substitution elasticity $(v)$ enlarge the potential for labor market distortions. The welfare costs per dollar of all three taxes rise with higher values for this elasticity. In addition, the excess costs per dollar increase with this elasticity, in keeping with the predictions of the theoretical model, although the effects on excess costs are fairly small.

The higher the value of the intertemporal elasticity of substitution in consumption $(\sigma)$, the greater the potential for efficiency or welfare losses under policies that distort the capital market, or intertemporal allocation of resources. For all three taxes considered, welfare costs rise with this elasticity. However, excess costs rise only for the BTU tax. The inverse relationship between $\sigma$ and the gasoline tax's excess cost is consistent with the fact that the gasoline tax is effectively a narrow-based consumption tax whose burden falls primarily on labor. Relative to the personal income tax increase, it imposes a smaller 
additional tax burden on capital. Hence, the excess cost of the gasoline tax diminishes the larger is $\sigma$ and the greater the potential for capital market distortions.

Higher energy demand elasticities raise welfare costs per dollar, with larger proportionate increases for the energy taxes. Hence excess costs rise as well.

The effects of higher pre-existing labor and capital taxes are similar to those of higher labor and capital elasticities. Higher pre-existing labor taxes expand the potential for labor market distortions. Correspondingly, and in parallel with the effects of a higher labor-leisure substitution elasticity, welfare costs and excess costs rise with pre-existing tax rates. Higher pre-existing capital taxes expand the potential for capital market distortions. In parallel with the effects of higher values for $\sigma$, welfare costs rise, excess costs rise for the BTU tax, and excess costs fall for the gasoline tax.

Interestingly, although different parameter values can significantly affect the magnitudes of the excess costs of the energy taxes, excess costs are positive in all cases. For a fairly wide range of specifications for pre-existing taxes and parameter values, the double dividend hypothesis thus fails. This does not mean that it is impossible to produce the double dividend with the numerical model. Indeed, the model does generate the double dividend under special parameter values and revenue-replacement methods. In particular, we can produce the double dividend under the gasoline tax increase if the intertemporal elasticity of substitution in consumption is 1.9 or higher and all revenues are retumed in the form of reduced marginal tax rates on capital income. The high value for $\sigma$ implies large gains to the extent that a revenue-neutral tax swap reduces the burden on capital. Combining the gasoline tax increase with a reduction in capital tax rates yields a significant reduction in capital's tax burden. Although this demonstrates the possibility of a double dividend, we consider this circumstance relatively unusual, both in terms of assumed elasticities ${ }^{27}$ and in terms of the recycling method.

\footnotetext{
${ }^{27}$ Estimated values for $\sigma$ are typically below unity. Results from Hall (1988), for example, indicate that $\sigma$ is below 0.2 .
} 


\section{v. Conclusions}

This paper has employed analytical and numerical models to examine the costs of revenue-neutral environmental tax reforms. We find that the substitution of environmentally motivated taxes for traditional income taxes typically involves a (gross) cost: the double dividend does not materialize. This result runs contrary to what some analysts have suggested but is consistent with an emerging theoretical literature on the issue. Underlying this result is the fact that environmental taxes are implicit factor taxes that not only generate factor market distortions similar to those of income taxes but also impose additional distortions of their own in other markets.

Earlier analytical work offered little scope for the double dividend because it did not consider preexisting inefficiencies in the tax treatment of labor and capital. In contrast with the earlier models, the analytical model in this paper is able to examine how the initial tax treatment of labor and capital affects the prospects for a double dividend. The model shows that to the extent that a revenue-neutral tax reform shifts the burden of taxation to the less efficient (undertaxed) factor, the prospects for a double dividend are enhanced. The numerical model's simulations indicate that this tax shifting effect is pronounced in the case of a consumer gasoline tax but fairly small in the case of a Btu tax. In neither case, however, is the tax shifting effect strong enough to yield the double dividend. This result is robust to a range of assumptions about values for key parameters.

The absence of a double dividend does not vitiate the case for green taxes. But it does compel policy analysts to invoke environmental benefits to make the efficiency case for such taxes. Further research that helps reduce uncertainties as to the magnitudes of these benefits will be of considerable use to policymakers contemplating environmental tax reform. 


\section{References}

Auerbach, Alan J., and Laurence J. Kotlikoff, 1987. Dynamic Fiscal Policy. Cambridge, MA: Cambridge University Press.

Armington, P.S., 1969. "A Theory of Demand for Products Distinguished by Place of Production," I.M.F. Staff Papers, pp. 159-76.

Ballard, Charles L., and Steven G. Medema, 1993. "The Marginal Efficiency Effects of Taxes and Subsidies in the Presence of Extemalities." Journal of Public Economics 52:199-216.

Ballard, Charles L., John B. Shoven and John Whalley, 1985.

"General Equilibrium Computations of the Marginal Welfare Costs of Taxes in the U.S." American Economic Review 75(1):128-138.

Bovenberg, A. Lans, 1995. "Environmental Policy, Distortionary Taxation, and Employment: Pollution Taxes and the Double Dividend." Forthcoming in C. Carraro (ed.), Recent Advances in Environmental Economics. Dordrecht: Kluwer.

Bovenberg, A. Lans, and Ruud A. de Mooij, 1994. "Environmental Levies and Distortionary Taxation." American Economic Review 84(4):1085-9.

Bovenberg, A. Lans, and F. van der Ploeg, 1994. Environmental Policy, Public Finance and the Labour Market in a Second-Best World." Journal of Public Economics, Vol. 55, pp. 349-70.

Bovenberg, A. Lans, and Lawrence H. Goulder, 1994. "Optimal Environmental Taxation in the Presence of Other Taxes: An Applied General Equilibrium Analysis." Working Paper, Stanford University, May.

Cruz, Miguel, and Lawrence H. Goulder, 1992. "An Intertemporal General Equilibrium Model for Analyzing U.S. Energy and Environmental Policies: Data documentation." Unpublished manuscript, Stanford University.

Diamond, Peter, and J. Mirrlees, 1971. "Optimal Taxation and Public Production I: Production Efficiency and II: Tax Rules," American Economic Review 61.

Gaskins, Darius and John Weyant, 1994. The Costs of Controlling Greenhouse Gas Emissions. Stanford, CA: Stanford University Press, forthcoming.

Goulder, Lawrence H., 1992. "An Intertemporal General Equilibrium Model for Analyzing U.S. Energy and Environmental Policies: Model Structure." Unpublished manuscript, Stanford University.

, 1994. "Energy Taxes: Traditional Efficiency Effects and Environmental Implications."

In James M. Poterba, ed., Tax Policy and the Economy 8. Cambridge, Mass.: MIT Press, June. 1995a. "Environmental Taxation and the 'Double Dividend:' A Reader's Guide." National Bureau of Economic Research Working Paper No. 4896, October. (Forthcoming in International 
Tax and Public Finance.)

1995b. "Effects of Carbon Taxes in an Economy with Prior Tax Distortions: An Intertemporal General Equilibrium Analysis." Working Paper, Stanford University, June. (Forthcoming in Journal of Environmental Economics and Management.)

Hall, Robert, 1988. "Intertemporal Substitution in Consumption." Journal of Political Economy 96(2):339-357.

Lee, Dwight R., and Walter S. Misiolek, 1986. "Substituting Pollution Taxation for General Taxation: Some Implications for Efficiency in Pollution Taxation." Journal of Environmental Economics and Management 13:338-347.

Manne, Alan S., and Richard G. Richels, 1992. Buying Greenhouse Insurance: The Economic Costs of $\mathrm{CO}_{2}$ Emissions Limits. Cambridge, Mass.: MIT Press.

Oates, Wallace E., 1991. "Pollution Charges as a Source of Public Revenues." Resources for the Future Discussion Paper QE92-05. Resources for the Future, Washington, D.C., November.

1995. "Green Taxes: Can We Protect the Environment and Improve the Tax System at the Same Time?" Forthcoming, Southern Economic Journal.

Parry, Ian W.H., 1994. "Pollution Taxes and Revenue Recycling." Working Paper, Economic Research Service, U.S. Department of Agriculture, April.

Pearce, David W., 1991. "The Role of Carbon Taxes in Adjusting to Global Warming." Economic Journal 101, pp. 938-948.

Poterba, James M., 1993. "Global Warming: A Public Finance Perspective." Journal of Economic Perspectives 7(4), 47-63.

Repetto, Robert, Roger C. Dower, Robin Jenkins, and Jacqueline Geoghegan, 1992. Green Fees: How a Tax Shift Can Work for the Environment and the Economy. World Resources Institute, November.

Rotemberg, Julio, and Michael Woodford, 1994. "Energy Taxes and Aggregate Economic Activity." In James M. Poterba, ed., Tax Policy and the Economy 8. Cambridge, Mass.: MIT Press, June.

Summers, Lawrence H., 1981. "Taxation and Corporate Investment: A q-Theory Approach." Brookings Papers on Economic Activity, January, 67-127.

Terkla, David, 1984. "The Efficiency Value of Effluent Tax Revenues." Journal of Environmental Economics and Management 11:107-23. 


\section{Aggregate Effects of Energy and Income Tax Policies}

Revenue Replacement via Lump-Sum Tax Cuts

(percentage changes from reference case)

(a)

Real

GDP

(b)

Real

Consumption

(c)

Real

Private

Fixed

Investment
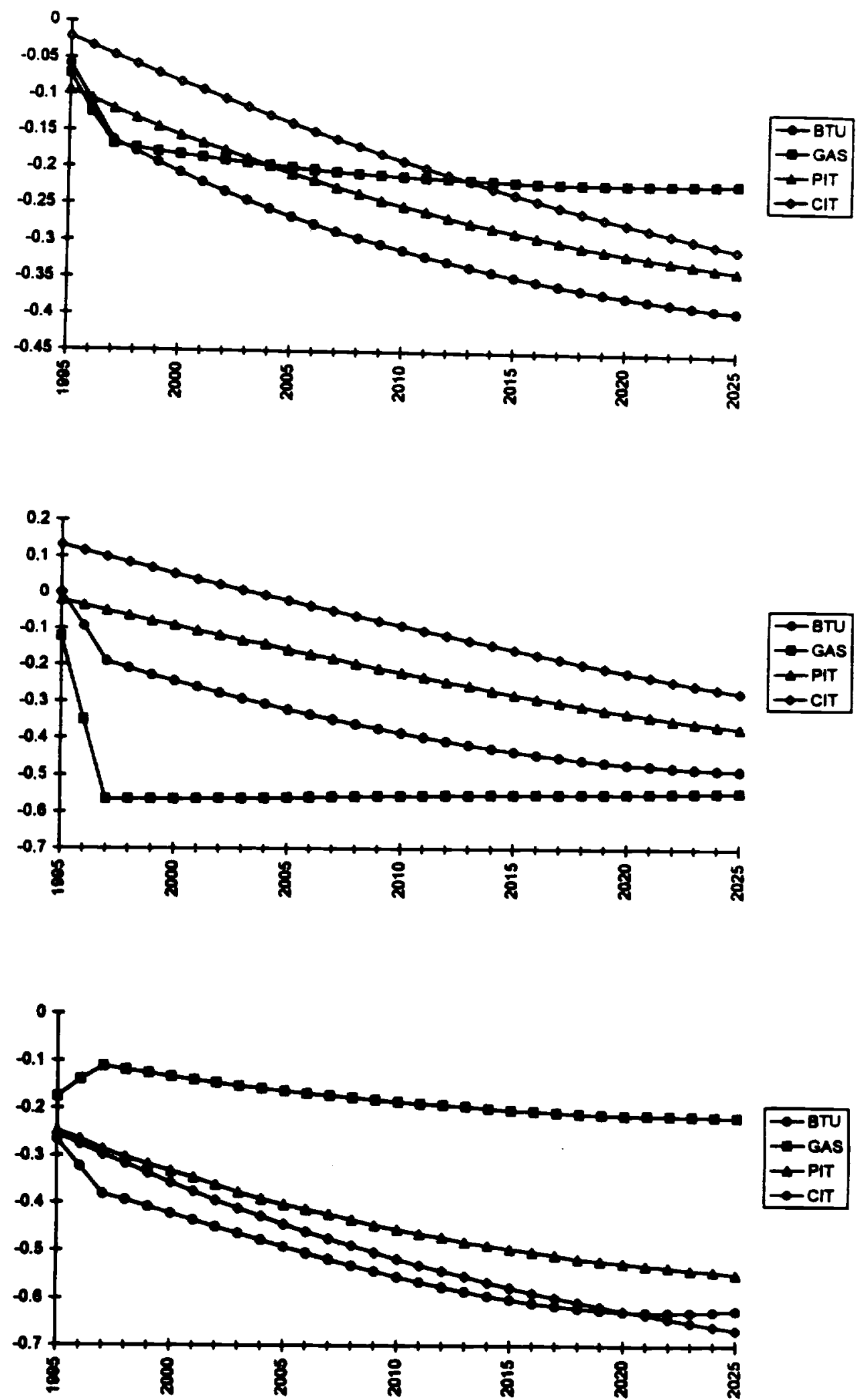


\section{Aggregate Effects of Energy and Income Tax Policies}

Revenue Replacement via Personal Income Tax Cuts

(percentage changes from reference case)

(a)

Real

GDP

(b)

Real

Consumption

(c)

Real

Private

Fixed

Investment
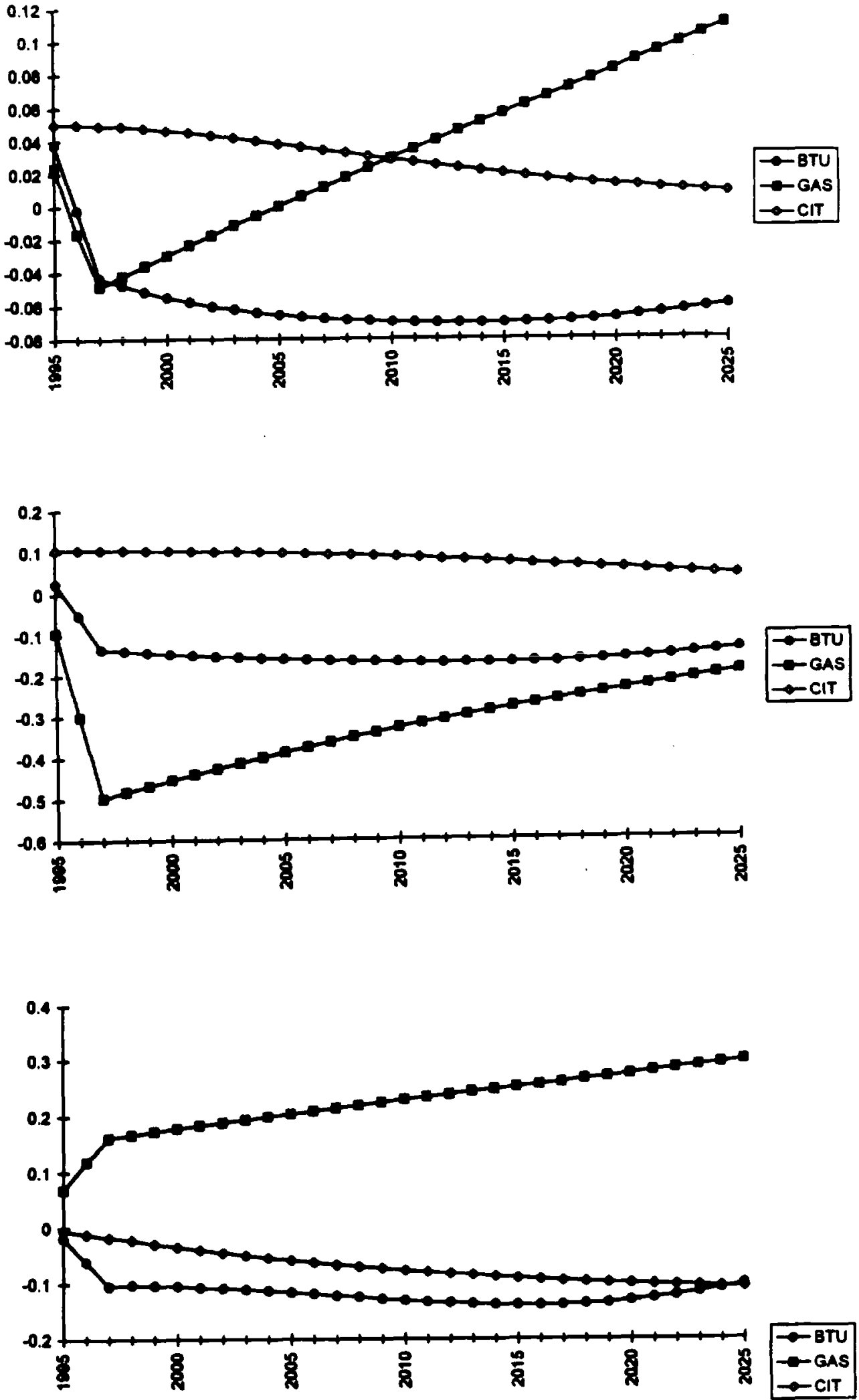
Table 1

Industry and Consumer Good Categories

Industries

1. Agriculture and Non-Coal Mining

2. Coal Mining

3. Crude Petroleum and Natural Gas

4. Synthetic Fuels

5. Petroleum Refining

6. Electric Utilities

7. Gas Utilities

8. Construction

9. Metals and Machinery

10. Motor Vehicles

11. Miscellaneous Manufacturing

12. Services (except housing)

13. Housing Services

\section{Consumer Goods}

1. Food

2. Alcohol

3. Tobacco

$4 . \quad$ Utilities

5. Housing Services

6. Fumishings

7. Appliances

8. Clothing and Jewelry

9. Transportation

10. Motor Vehicles

11. Services (except financial)

12. Financial Services

13. Recreation, Reading, \& Misc.

14. Nondurable, Non-Food Household Expenditure

15. Gasoline and Other Fuels

16. Education

17. Health 
Table 2

\section{Welfare Impacts}

Welfare Cost

Per Dollar of Revenue

\author{
Lump-Sum \\ Tax Replacement
}

Personal Income

Tax Replacement

BTU Tax

.656

Consumer-Level

Gasoline Tax Increase

Personal Income

Tax Increase

Corporate Income

Tax Increase

.438

.093 
Table 3

Impacts of Taxes on Factor Prices and Supplies

(percentage changes from baseline)

\begin{tabular}{cccc}
\multicolumn{4}{c}{ Years after Policy Introduction } \\
\hline 1 & 2 & 5 & 30
\end{tabular}

"Single Tax" Policies:

Btu Tax, Lump-Sum Repl.

$\begin{array}{lllll}w & -0.250 & -0.390 & -0.446 & -0.655 \\ r & -0.083 & -0.239 & -0.179 & -0.084 \\ L & -0.124 & -0.140 & -0.121 & -0.049 \\ K & -0.017 & -0.035 & -0.092 & -0.364\end{array}$

Gasoline Tax Increase, Lump-Sum Repl.

$\begin{array}{lrrrr}w & -0.722 & -1.069 & -1.058 & -0.983 \\ r & 0.095 & -0.007 & -0.027 & -0.005 \\ L & -0.266 & -0.335 & -0.331 & -0.298 \\ K & -0.011 & -0.019 & -0.031 & -0.069 \\ \text { Tax Increase, Lump-Sum Repl. } & & & & \\ w & & & & \\ r & -0.333 & -0.347 & -0.404 & -0.655 \\ L & -0.104 & -0.108 & -0.105 & -0.053 \\ K & -0.277 & -0.274 & -0.265 & -0.212 \\ & -0.015 & -0.030 & -0.072 & -0.313\end{array}$

Substitution of Environmental Tax

For Personal Tax:

Btu Tax, Personal Tax Repl.

$\begin{array}{lrrrr}w & 0.083 & -0.042 & -0.042 & 0.014 \\ r & 0.031 & -0.125 & -0.074 & -0.053 \\ L & 0.157 & 0.139 & 0.149 & 0.163 \\ K & -0.001 & -0.005 & -0.019 & -0.037\end{array}$

Gasoline Tax Increase, Personal Tax Repl.

$\begin{array}{lrrrr}w & -0.375 & -0.694 & -0.571 & -0.307 \\ r & 0.216 & 0.111 & 0.076 & 0.057 \\ L & 0.013 & -0.057 & -0.061 & -0.084 \\ K & 0.004 & 0.012 & 0.041 & 0.252\end{array}$

Note: $w, r, L$, and $K$ respectively refer to the after-tax real wage, after-tax real rate of return, aggregate real labor supply, and aggregate real capital stock. 
Table 4

Significance of Breadth of Tax Base

Welfare Cost

Per Dollar
Excess Cost

Per Dollar

1. Taxes on Intermediate Inputs
.656
.470
b. Broad Intermediate Input Tax
a. Btu Tax
.279

2. Taxes on Consumption

a. Gasoline Tax Increase

.594

.383

b. Broad Consumption Tax

.211

$-.166$

3. Tax on Income

Personal Income Tax Increase 
Table 5

Sensitivity Analysis

\section{Welfare Cost per Dollar of Revenue}

$\begin{array}{ccc}\text { Btu Tax } & \text { Cons.-Level } & \text { Pers. Income } \\ \text { Gasoline Tax } & \text { Tax Increase }\end{array}$

0.656

0.483

0.705

b. high $(v=.85)$

3. Intertemporal Elasticity of Substitution

in Consumption $(\sigma)$

a. low $(\sigma=.33)$

b. high $(\sigma=.66)$

0.768

0.458

0.726

0.370

0.507

0.165

0.552

0.776

0.339
0.491

0.802

a. low $(-25 \%)$
b. high $(+25 \%)$

5. Pre-existing Tax Rates $\left(\tau_{\mathrm{L}}, \tau_{\mathrm{k}}\right)$
a. low $\tau_{\mathrm{L}}(-25 \%)$
b. high $\tau_{\mathrm{L}}(+25 \%)$
c. low $\tau_{\mathrm{K}}(-25 \%)$
d. high $\tau_{\mathrm{k}}(+25 \%)$

0.581

0.729

0.492

0.833

$\begin{array}{ll}0.509 & 0.311 \\ 0.668 & 0.444 \\ 0.448 & 0.216 \\ 0.758 & 0.548\end{array}$

Excess Cost per Dollar of Revenue

Cons.-Level

Btu Tax Gasoline Tax

0.277

0.215

0.275

0.199

$0.279 \quad 0.221$

$0.261 \quad 0.219$

$0.293 \quad 0.205$

$0.219 \quad 0.213$

$0.311 \quad 0.285$

$\begin{array}{ll}0.270 & 0.198 \\ 0.285 & 0.224 \\ 0.276 & 0.232\end{array}$

$0.285 \quad 0.210$

Notes:

Figures in columns 1-3 are the equivalent variation divided by the present value of gross tax revenues from the policy change. Figures in the last two columns are the difference in results for the energy tax in question (from column 1 or 2) and the personal income tax increase (column 3 ). Central case values for the labor-leisure substitution elasticity $(v)$ and intertemporal elasticitity of substitution $(\sigma)$ are 0.77 and 0.5 , respectively. (See appendix for functional forms.) Values of $0.50,0.77$, and 0.85 imply uncompensated (compensated) wage elasticities of labor supply of -0.067 $(0.588), 0.150(0.936)$ and $0.214(1.078)$, respectively, at benchmark prices. The variables $\tau_{\mathrm{L}}$ and $\tau_{\mathrm{K}}$ denote the marginal tax rates on individual labor and capital income; central case values are .230 and .229 , respectively. 


\section{Appendix A: Welfare Efrects of Tax Reforms}

Firms equalize the marginal product of each input to its user cost:

$$
\begin{aligned}
& F_{L}(1, K / L, R / L)=w\left(1+t_{L}\right) \\
& F_{K}(1, K / L, R / L)=p_{R}\left(1+t_{R}\right) \\
& F_{R}(1, K / L, R / L)=p_{R}\left(1+t_{R}\right)
\end{aligned}
$$

The last two first-order conditions yield the demands for $K$ and $R$ conditional on the level of employment:

$$
K=L k\left[p_{R}\left(1+t_{R}\right) ; p_{R}\left(1+t_{R}\right)\right] ; R=\operatorname{Lr}\left[p_{K}\left(1+t_{R}\right) ; p_{R}\left(1+t_{R}\right)\right]
$$

Substituting (A.4) into (A.1), we find the producer wage in terms of the producer prices of capital and the polluting resource:

$$
w\left(1+t_{R}\right)=\Omega\left(p_{R}\left(1+t_{R}\right) ; p_{R}\left(1+t_{R}\right)\right)
$$

where

$$
\frac{\partial \Omega}{\partial p_{K}\left(1+t_{R}\right)}=-\frac{K}{L} ; \frac{\partial \Omega}{\partial p_{R}\left(1+t_{R}\right)}=-\frac{R}{L}
$$

The representative household maximizes utility $u(m(C, I-L), G, E]$ subject to the household budget constraint. This yields:

$$
\begin{gathered}
u_{c}=\lambda \\
u_{(1-L)}=\lambda w
\end{gathered}
$$

where $\lambda$ represents the marginal utility of income.

The welfare effects of a revenue-neutral change in the tax mix (i.e., a change in taxes such that $d G=0$ ) are derived by taking the total differential of utility:

$$
d u=u_{c} d C-u_{1-L} d L+u_{E} e_{R} d R
$$

Substituting (A.7) and (A.8) into (A.9), we can write:

$$
\frac{d u}{u_{C}}=d C-w d L+\frac{u_{E} e_{R} d R}{u_{C}}
$$

Taking the total differential of balance of payments equilibrium (3) and substituting (A.1), (A.2), and (A.3), we find: 


$$
w\left(1+t_{L}\right) d L+p_{K} t_{K} d K+p_{R} t_{R} d R=d C
$$

Using (A.11) to eliminate $d C$ from (A.10), we arrive at:

$$
\frac{d u}{u_{C}}=-\frac{u_{E}}{u_{C}}\left[\left(-e_{R}\right) d R\right]+\left[w t_{L} d L+p_{R} t_{R} d R+p_{K} t_{K} d K\right]
$$

By taking the total differential of the government budget constraint (2) (with $d G=0$ ) and using (A.5) and (A.6), we find:

$$
w t_{L} d L+p_{R} t_{R} d R+p_{K} t_{K} d K=L d W
$$

Substitution of (A.13) into (A.12) yields (4).

\section{Appendix B: Solution to the Analytical Model}

Log-linearizing the production function and substituting the log-linearized version balance-of-payments equilibrium (A.7) to eliminate output, we arrive at:

$$
\omega_{L} \tilde{L}=\omega_{C} \tilde{C}-\omega_{R} \theta_{R} \tilde{R}-\omega_{R} \theta_{K} \tilde{K}
$$

where $\omega_{c}$ decreases the share of consumption in output.

We want to express the endogenous variable at the right-hand side of (B.1) in terms of $\bar{L}$ and $\bar{w}$.

To find the expressions for $\tilde{R}$ and $\tilde{K}$, we log-linearize (A.1), (A.2), and (A.3), to arrive at:

$$
\begin{aligned}
& \tilde{R}=\tilde{L}+\sigma\left[\left(\bar{w}+\bar{t}_{L}\right)-\tilde{t}_{R}\right] \\
& \tilde{K}=\tilde{L}+\sigma\left[\left(\bar{w}+\bar{t}_{\nu}\right)-\tilde{t}_{R}\right]
\end{aligned}
$$

Log-linearizing (A.5) and substituting (A.6), we find:

$$
\omega_{L}\left(\bar{w}+\tilde{t}_{L}\right)+\omega_{R} \bar{t}_{R}+\omega_{K} \bar{t}_{K}=0
$$

\section{Endogenous Capital Income $\operatorname{Tax}\left(\bar{t}_{L}=0\right)$}

Substitution of (B.4) into (B.3) to eliminate $i_{k}$ yields (with $\bar{t}_{L}=0$ ): 


$$
\bar{K}=\bar{L}+\frac{\sigma}{\omega_{K}}\left[\left(1-\omega_{R}\right) \bar{w}+\omega_{R} \bar{t}_{R}\right]
$$

We now substitute (B.2) (with $\bar{t}_{L}=0$ ), (B.5), and the log-linearized household budget constraint

$$
\omega_{c} \bar{C}=\omega_{L}\left(1-\theta_{\nu}\right)[\bar{w}+\bar{L}]
$$

into (B.1) to eliminate, respectively, $\tilde{R}, \tilde{K}$, and $\tilde{C}$ :

$$
\left[\theta_{L} \omega_{L}+\theta_{R} \omega_{R}+\theta_{R} \omega_{R}\right] \tilde{L}=\left[\left(1-\theta_{L}\right) \omega_{L}-\sigma\left[\theta_{R} \omega_{R}+\theta_{R}\left(1-\omega_{R}\right)\right]\right] \bar{w}+\left(\theta_{R}-\theta_{R}\right) \omega_{R} \sigma \bar{t}_{R}
$$

We can solve for $\bar{L}$ and $\bar{w}$ by using the labor supply function,

$$
\tilde{L}=\eta_{L} \bar{w}
$$

This yields (5). Substituting (5) and (B.8) into (B.2) and (B.5), we find (6) and (7).

2. Endogenous Labor Income $\operatorname{Tax}\left(\tilde{f}_{R}=0\right)$

Substitution of (B.4) into (B.2) and (B.3) to eliminate $\left(\bar{w}+\bar{t}_{L}\right)$ yields (with $\bar{t}_{K}=0$ ):

$$
\begin{gathered}
\bar{R}=\bar{L}-\frac{\sigma}{\omega_{L}}\left(1-\omega_{R}\right) \bar{t}_{R} \\
\bar{K}=\bar{L}-\frac{\sigma}{\omega_{L}} \omega_{R} \bar{t}_{R}
\end{gathered}
$$

Substituting (B.9), (B.10), and (B.6) into (B.1), we arrive ar:

$$
\left[\theta_{L} \omega_{L}+\theta_{R} \omega_{R}+\theta_{R} \omega_{R}\right] \bar{L}=\left(1-\theta_{L}\right) \omega_{L} \bar{w}+\left[\theta_{R}\left(1-\omega_{R}\right)+\theta_{R} \omega_{R}\right] \frac{\omega_{R}}{\omega_{L}} \sigma \bar{i}_{R}
$$

Using (B.8) to eliminate $\bar{L}$ from (B.11), we find (8). Substitution of (8) into (B.8) and the result into (B.9) and (B.10) yields (9) and (10). 


\section{Structure}

\section{A. Production}

1. Technology

a. General Features

Table Al indicates the nested production structure. In each industry $i$, gross output $X_{i}$ is produced using inputs of labor $\left(L_{1}\right)$, capital $\left(K_{1}\right)$, an energy composite $\left(\bar{E}_{1}\right)$ and a materials composite $\left(\bar{M}_{1}\right)$. The production function has the following form:

$$
X_{1}=f_{1}\left[g_{11}\left(L_{i}, K_{i}\right), g_{2}\left(\bar{E}_{1}, \bar{M}_{i}\right)\right]-\phi_{1}\left(I / K_{1}\right) I_{1}
$$

The functions $f_{i}, g_{1 i}$, and $g_{2 i}$ are CES. Hence the function $f$ can be written as:

$$
f\left(g_{1}, g_{2}\right)=\gamma_{f}\left[\alpha_{f} g_{1}^{p_{t}}+\left(1-\alpha_{f}\right) g_{2}^{p_{f}}\right]^{1 / p_{t}}
$$

where the industry subscript has been suppressed and where $\gamma_{f}, \alpha_{f}$, and $\rho_{f}$ are parameters. The parameter $\rho$ is related to $\sigma_{f}$, the elasticity of substitution between $g_{1}$ and $g_{2}: \rho=(\sigma-1) / \sigma$. Analogous expressions apply for the functions $g_{1}$ and $g_{2}$.

The second term in equation (1) represents the loss of output associated with installing new capital (or dismantling existing capital). Per-unit adjustment costs, $\phi$, are given by:

$$
\phi(I / K)=\frac{(\xi / 2)(I / K-\delta)^{2}}{I / K}
$$

where $l$ represents gross investment (purchases of new capital goods) and $\xi$ and $\delta$ are parameters. The parameter $\delta$ denotes the rate of economic depreciation of the capital stock.

The energy composite $\left(\bar{E}_{i}\right)$ in equation (1) is a CES function of the specific energy products of the different energy industries:

4a)

$$
\begin{aligned}
& \bar{E}=\bar{E}\left(E_{1}, E_{2}, \ldots, E_{s}\right) \\
& =\gamma_{\bar{E}}\left[\sum_{j=1}^{3} \alpha_{\bar{E}_{i}} E_{j}^{p_{r}}\right]^{1 / p_{r}}
\end{aligned}
$$

\footnotetext{
'A more comprehensive description of the structure of the model is in Goulder (1992). Detailed documentation of the data and parameters for the model is provided in Cruz and Goulder (1992).
} 


\section{Table A1: Nested Production Structure}

$$
\begin{aligned}
& X=f\left(g_{1}, g_{2}\right)-\phi(l / K) I \\
& g_{1}=g_{1}(L, K) \\
& g_{2}=g_{2}(E, M) \\
& E \quad=\quad E\left(E_{1}, \ldots, E_{\xi}\right) \\
& M \quad=\quad M\left(M_{1}, \ldots, M_{7}\right) \\
& E_{i} \quad=\quad E_{i}\left(E D_{i}, E F_{i}\right) \\
& M_{1}=M_{1}\left(M D_{i}, M F_{i}\right) \\
& i=1, \ldots, 5 \\
& i=1, \ldots, 7
\end{aligned}
$$

Note: $\quad$ All functions are CES in form except for $\$(l / K)$, which is quadratic in $I / K$.

Table A2: Nested Utility Structure

Function:

$$
\begin{aligned}
& \mathrm{U}_{\mathrm{t}}\left(\mathrm{C}_{\mathrm{t}}, \mathrm{C}_{\mathrm{t}+1}, \ldots, \mathrm{C}_{1}, \ldots\right) \\
& \mathrm{C}_{\mathbf{1}}\left(\tilde{\mathrm{C}}_{\mathrm{i}}, \ell\right) \\
& \mathrm{C}_{\mathrm{s}}\left(\overline{\mathrm{C}}_{\mathrm{i}, \mathrm{s}}, \ldots, \overline{\mathrm{C}}_{\mathrm{i}, \mathrm{s}}, \ldots, \overline{\mathrm{C}}_{17, \mathrm{~s}}\right) \\
& \overline{\mathrm{C}}_{\mathrm{i}, \mathrm{s}}\left(\mathrm{CD}_{\mathrm{i}, \mathrm{s}}, \mathrm{CF}_{\mathrm{i}, \mathrm{s}}\right)
\end{aligned}
$$

\section{Functional Form:}

constant intertemporal elasticity of substitution

CES

Cobb-Douglas

CES

\section{Key:}

$U$

C,

$\bar{C}$,

!

$\vec{C}_{i, s}$

$C D_{i,}$

$C F_{i, s}$
$=$ intertemporal utility evaluated from period $t$

$=$ full consumption in period $s$

$=$ overall goods consumption in period $s$

$=$ leisure in period $s$

$=$ consumption of composite consumer good $i$ in period $s$

$=$ consumption of domestically produced consumer good $i$ in period $s$

$=$ consumption of foreign produced consumer good $i$ in period $s$ 
where $\sum_{j=1}^{5} \alpha_{\bar{E} j}=1$. The subscripts to $E$ in equations (4a) and (4b) correspond to energy industries as follows:

$\underline{\text { Subscript }}$

Energy Industry

1
2
3
4
5

Coal mining

Oil\&gas extraction and synthetic fuels

Petroleum refining

Electricity

Processed natural gas

Oil\&gas and synthetic fuels combine as one input in the energy composite, reflecting the fact that these fuels are treated as perfect substitutes in production. ${ }^{2}$

Similarly, the materials composite $\left(\bar{M}_{1}\right)$ in equation (1) is a CES function of the specific materials products of the 7 non-energy industries:

5a)

$$
\bar{M}=\bar{M}\left(M_{1}, M_{2}, \ldots, M_{7}\right)
$$

$$
=\gamma_{\bar{M}}\left[\sum_{j=1}^{7} \alpha_{\bar{M} j} M_{j}^{p_{j}}\right]^{1 / p_{d}}
$$

where $\sum_{j=1}^{7} \alpha_{\bar{M} j}=1$. The subscripts to $M$ in equations (5a) and (5b) correspond to materials (non-energy) industries as follows:

Subscript

1
2
3
4
5
6
7

\section{Materials Industry}

Agriculture and mining (except coal mining)

Construction

Metals and machinery

Motor vehicles

Miscellaneous manufacturing

Services (except housing services)

Housing services

The elements $E_{j}(j=1, \ldots, 5)$ and $M_{j}(j=1, \ldots, 7)$ in the $\bar{E}$ and $\bar{M}$ functions are themselves $C E S$ composites of domestically produced and foreign made inputs:

6)

$$
\begin{aligned}
& E_{j}=\gamma_{E j}\left[\alpha_{B j} E D_{j}^{P_{y j}}+\left(1-\alpha_{E j}\right) E F_{j}^{P_{y}}\right]^{1 / \rho_{z j}}, j=1, \ldots, 5 \\
& M_{j}=\gamma_{M_{j}}\left[\alpha_{w_{j}} M D_{j}^{\rho_{w j}}+\left(1-\alpha_{M_{j}}\right) M F_{j}^{\rho_{w j}}\right]^{1 / \rho_{w /}}, j=1, \ldots, 7
\end{aligned}
$$$$
\text { 7) }
$$

${ }^{2} \mathrm{E}_{2}$ denotes the total quantity (in energy-equivalent units) of oil\&gas plus synfuels:

$$
E_{2}=E_{o g}+E_{s}
$$


where $E D_{j}$ and $E F_{j}$ denote domestic and foreign energy inputs of type $j$, and $M D_{j}$ and $M F_{j}$ denote domestic and foreign materials inputs of type $j$.

\section{b. Endogeneity of $\gamma$ in the Oil\&Gas Production Function}

In industries other than oil\&gas, the element $\gamma_{f}$ in the production function is parametric. In the oil\&gas industry, $\gamma_{f}$ is a decreasing function of cumulative oil\&gas extraction:

$$
\gamma_{f, t}=\varepsilon_{1}\left[1-(Z, / \bar{Z})^{2}\right]
$$

where $\varepsilon_{1}$ and $\varepsilon_{2}$ are parameters, $Z_{1}$ represents cumulative extraction as of the beginning of period $t$, and $\bar{Z}$ is the original estimated total stock of recoverable reserves of oil\&gas (as estimated from the benchmark year). The following equation of motion specifies the evolution of $Z_{i}$ :

$$
Z_{t+1}=Z_{t}+X_{t}
$$

Equation (8) implies that the production function for oil and gas shifts downward as cumulative oil\&gas extraction increases. This addresses the fact that as reserves are depleted, remaining reserves become more difficult to extract and require more inputs per unit of extraction.

\section{Behavior of Firms}

In each industry, managers of firms are assumed to serve stockholders in aiming to maximize the value of the firm. The objective of firm-value maximization determines firms' choices of input quantities and investment levels in each period of time.

The value of the firm can be expressed in terms of dividends and new share issues, which in turn depend on profits in each period. The firm's profits during a given period are given by:

$$
\pi=\left(1-\tau_{d}\right)\left[p X-w\left(1+\tau_{L}\right) L-E M C O S T-i D E B T-T P R O P\right]+\tau_{d}(D E P L+D E P R)
$$

where $\tau_{a}$ is the tax rate on profits, $p$ is the output price net of output taxes, $w$ is the wage rate net of indirect labor taxes, $\tau_{\mathrm{L}}$ is rate of the indirect tax on labor, EMCOST is the cost to the firm of energy and materials inputs. $i$ is the gross-of-tax interest rate paid by the firm, DEBT is the firm's current debt, TPROP is property tax payments, DEPL is the current gross depletion allowance, and DEPR is the current gross depreciation allowance. TPROP equals $\tau_{p} p_{k,+1} K_{t}$, where $\tau_{p}$ is the property tax rate, $p_{k}$ is the purchase price of a unit of new capital, and $S$ is the time period. Current depletion allowances, DEPL, are a constant fraction $\beta$ of the value of current extraction: $D E P L=\beta p X$. Current depreciation allowances, $D E P R$, can be expressed as $\delta^{T} K^{T}$, where $K^{T}$ is 
the depreciable capital stock basis and $\delta^{T}$ is the depreciation rate applied for tax purposes. ${ }^{3}$

In equation (10), EMCOST is given by:

11)

$$
\begin{aligned}
E M C O S T & =\sum_{j=1}^{5}\left(1+\tau_{E j}\right)\left(p_{E D, j} E D_{j}+p_{E F, j} E F_{j}\right) \\
& +\sum_{j=1}^{7}\left(1+\tau_{m j}\right)\left(p_{M D, j} M D_{j}+p_{M F, j} M F_{j}\right)
\end{aligned}
$$

where the subscripts for energy and materials correspond to industries as indicated above; and where $\tau_{E}$ and $\tau_{M}$ denote the tax rates applying to the firm's use of intermediate inputs, and $p_{E D_{j}}$ and $p_{E F_{j}}\left(p_{M D_{j}}\right.$ and $\left.p_{M F j}\right)$ are the pre-tax prices of domestic and foreign energy (materials) inputs of type $j .^{4}$

The following accounting or cash-flow identity links the firm's sources and uses of revenues:

$$
\pi+B N+V N=D I V+I E X P
$$

The left-hand side is the firm's source of revenues: profits, new debt issue (BN), and new share issues (VN) . The uses of revenues on the right-hand side are investment expenditure (IEXP) and dividend payments (DIV). Negative share issues are equivalent to share repurchases, and represent a use rather than source of revenue.

Firms pay dividends equal to a constant fraction, $a$, of profits net of economic depreciation, and maintain debt equal to a constant fraction, $b$, of the value of the existing capital stock. Thus:

$$
\begin{gathered}
D I V_{s}=a\left[\pi,+\left(p_{K, s}-p_{K, y-1}\right) K_{,}-\delta p_{K, s} K_{s}\right] \\
B N_{,} \equiv D E B T_{z+1}-D E B T_{s}=b\left(p_{K, s} K_{s+1}-p_{K, s-1} K_{s}\right)
\end{gathered}
$$

Investment expenditure is expressed by:

$$
I E X P,=\left(1-\tau_{\mathrm{x}}\right) p_{\mathrm{R}, \mathrm{I}} I_{\mathrm{s}}
$$

where $\tau_{x}$ is the investment tax credit rate. Of the elements in equation (12), new share issues, $V N$, are the

${ }^{3}$ For convenience, we assume that the accelerated depreciation schedule can be approximated by a schedule involving constant exponential tax depreciation.

'To simplify the exposition, we have not included in equations (10) and (11) subscripts identifying the given industry for which profits or input costs are calculated. It may be noted that the intermediate good taxes, $\tau_{\varepsilon_{j}}$ and $\tau_{\boldsymbol{w}_{j}}$, may differ across industries using a particular good as well as across intermediate goods.

In equation (11), for $j=2$ the expression $p_{E_{j}}\left(I+\tau_{g_{j}}\right) E_{j}$ is short-hand for $p_{o g}\left(l+\tau_{o g}\right) E_{o q}+p_{q j}(I+$ $\left.\tau_{f f}\right) E_{f f}$, where "og" refers to oil and gas and "sf" refers to synfuels. Since oilsgas and synfuels are perfect substitutes, it is always the case that gross-of-tax costs of these fuels to the firm are the same: that is, $p_{o g}\left(1+\tau_{o q}\right)$ $=p_{s f}\left(I+\tau_{q f}\right)$. However, when $\tau_{o g} \neq \tau_{q f}$, the net-of-tax prices $p_{o g}$ and $p_{q f}$ will differ. 
residual, making up the difference between $\pi+B N$ and $D I V+I E X P$.

Arbitrage possibilities compel the firm to offer its stockholders a rate of return comparable to the rate of interest on alternative assets.

$$
\left(1-\tau_{a}\right) D I V_{s}+\left(1-\tau_{v}\right)\left(V_{s+1}-V_{s}-V N_{s}\right)=\left(1-\tau_{b}\right) i, V_{s}
$$

The parameters $\tau_{e}, \tau_{v}$, and $\tau_{b}$ are the personal tax rates on dividend income (equity), capital gains, and interest income (bonds), respectively. The return to stockholders consists of the current after-tax dividend plus the after-tax capital gain (accrued or realized) on the equity value $(V)$ of the firm net of the value of new share issues. This return must be comparable to the after-tax return from an investment of the same value at the market rate of interest, $i$.

The firm's decision problem is completed by the equation of motion for the capital stock:

$$
K_{s+1}=(1-\delta) K,+I_{s}
$$

Capital is augmented by net investment. Cumulative extraction is augmented by the level of current output (or extraction). In the oil\&gas industry, the equation of motion (9) also applies.

\section{B. Household Behavior}

Consumption, labor supply, and saving result from the decisions of an infinitely-lived representative household maximizing its intertemporal utility with perfect foresight. The nested structure of the household's utility function is indicated in Table A2. In year $t$ the household chooses a path of "full consumption" $C$ to maximize

$$
U_{t}=\sum_{s=1}^{\infty}(1+\omega)^{t-1} \frac{\sigma}{\sigma-1} C_{r}^{\frac{0-1}{\sigma}}
$$

where $\omega$ is the subjective rate of time preference and $\sigma$ is the intertemporal elasticity of substitution in full consumption. $\mathrm{C}$ is a CES composite of consumption of goods and services $\dot{C}$ and leisure $\ell$ :

$$
C_{s}=\left[\frac{v-1}{C_{0}^{v}}+\alpha_{c}^{\frac{1}{v}} \frac{0-1}{v}\right]^{\frac{v}{v-1}}
$$

$v$ is the elasticity of substitution between goods and leisure; $\alpha_{c}$ is an intensity parameter for leisure.

The variable $\tilde{C}$ in (25) is a Cobb-Douglas aggregate of 17 composite consumer goods:

$$
\tilde{C},=\prod_{i=1}^{17} \bar{C}_{i, i, i}
$$

where the $\alpha_{c, i}(i=1, \ldots, 17)$ are parameters. The 17 types of consumer goods identified in the model are shown

'For a discussion of alternative specifications, see Poterba and Summers (1985). 
in Table 2 of the main text.

Consumer goods are produced domestically and abroad. Each composite consumer good $\bar{C}_{i}, i=1, \ldots, 17$, is a CES aggregate of a domestic and foreign consumer good of a given type:

$$
\bar{C}=\gamma_{\bar{c}}\left[\alpha_{\bar{c}} C D^{\rho_{\varepsilon}}+\left(1-\alpha_{\bar{c}}\right) C F^{\rho_{\varepsilon}}\right]^{1 / \rho_{\bar{c}}}
$$

In the above equation, $C D$ and $C F$ denote the household's consumption of domestically produced and foreign made consumer good of a given type at a given point in time. For simplicity, we have omitted subscripts designating the type of consumer good and the time period.

The household maximizes utility subject to the intertemporal budget constraint given by the following condition goveming the change in financial wealth, WK :

$$
W K_{t+1}-W K_{1}=\bar{r}_{\imath} W K_{1}+Y L_{1}+G T_{1}-\tilde{p}_{\imath} \tilde{C}_{1}
$$

In the above equation, $\bar{r}$ is the average after-tax return on the household's portfolio of financial capital, YL is after-tax labor income, GT is transfer income, and $\bar{p}$ is the price index representing the cost to the household of a unit of the consumption composite, $\bar{C}$.

\section{Government Behavior}

A single government sector approximates govemment activities at all levels -- federal, state, and local. The main activities of the government sector are purchasing goods and services (both non-durable and durable), to transferring incomes, and to raising revenue through taxes or bond issue.

\section{Components of Government Expenditure}

Government expenditure, $G$, divides into nominal purchases of nondurable goods and services $(G P)$, nominal government investment $(G I)$, and nominal transfers $(G T)$ :

$$
G_{1}=G P_{1}+G I_{1}+G T_{1}
$$

In the reference case, the paths of real $G P, G I$, and $G T$ all are specified as growing at the steady-state real growth rate, 8 . In simulating policy changes we fix the paths of GP, GI, and GT so that the paths of real government purchases, investment and transfers are the same as in corresponding years of the reference case. Thus, the expenditure side of the government ledger is largely kept unchanged across simulations. This procedure is expressed by:

$$
\begin{aligned}
& G P_{1}^{p} / P_{G, 1}^{p}=G P_{1}^{k} / P_{G, 1}^{k} \\
& G F_{1}^{p} / P_{A, 1}^{p}=G I_{t}^{k} / P_{G, 1}^{k}
\end{aligned}
$$


(24c)

$$
\mathrm{GT}_{\mathrm{t}}^{\mathrm{p}} / \mathrm{p}_{\mathrm{GT}, \mathrm{p}}^{\mathrm{p}}=\mathrm{GT}_{\mathrm{t}}^{\mathrm{R}} / \mathrm{p}_{\mathrm{O} \mathrm{T}, \mathrm{l}}^{\mathrm{R}}
$$

The superscripts $P$ and $R$ denote policy change and reference case magnitudes, while $p_{G P}, p_{G l}$, and $p_{G T}$ are price indices for $G P, G I$, and $G T$. The price index for government invesument, $p_{G l}$, is the purchase price of the representative capital good. The price index for transfers, $p_{G T}$, is the consumer price index. The index for government purchases, $p_{G P}$, is defined below.

\section{Allocation of Government Purchases}

GP divides into purchases of particular outputs of the 13 domestic industries according to fixed expenditure shares:

$$
\alpha_{G, i} G P=G P X_{i} p_{i}
$$

$G P X_{i}$ and $p_{1}$ are the quantity demanded and price of output from industry $i$, and $\alpha_{G, 1}$ is the corresponding expenditure share. The ideal price index for govemment purchases, $p_{G P}$, is given by:

$$
p_{G P}=\prod_{i=1}^{13} p_{i}^{\alpha_{0,1}}
$$

\section{Parameter Values}

\section{A. Elasticities of Substitution in Production}

Parameter:

Substitution

margin:

Producing Industry:

1. Agric. \& Non-coal Mining

2. Coal Mining

3. Oil \& Gas Extraction

4. Synthetic Fuels

5. Petroleum Refining

6. Electric Utilities

7. Gas Utilities

8. Construction $\sigma_{i}$

$\mathbf{g}_{1}-\mathbf{g}_{2}$

0.7

0.68

$0.7 \quad 0.80$

0.7

0.82

0.7

0.82

0.7

0.74

0.7

0.7

0.7 $\sigma_{12}$

$\sigma_{\mathrm{B}}$

E com-

E-M ponents $\sigma_{m}$

M components $\sigma_{2}$ dom-foreign inputs
0.7
1.45
0.6

1.08

0.6

1.14

0.7

1.04

0.6 (infinite)

0.7

1.04

0.6

(not traded)

0.7

1.04

0.6

2.21

0.7

0.97

0.6

1.0

0.7

1.04

0.6

1.0

0.7

1.04

0.6 


$\begin{array}{lllllll}\text { 9. Metals \& Machinery } & 0.7 & 0.91 & 0.7 & 1.21 & 0.6 & 2.74 \\ \text { 10. Motor Vehicles } & 0.7 & 0.80 & 0.7 & 1.04 & 0.6 & 1.14 \\ \begin{array}{l}\text { 11. Misc. } \\ \text { Manufacturing }\end{array} & 0.7 & 0.94 & 0.7 & 1.08 & 0.6 & 2.74 \\ \begin{array}{l}\text { 12. Services (except } \\ \text { housing) }\end{array} & 0.7 & 0.98 & 0.7 & 1.07 & 0.6 & 1.0 \\ \begin{array}{l}\text { 13. Housing Services } \\ \text { Hound }\end{array} & 0.7 & 0.80 & 0.7 & 1.81 & 0.6 & \text { (not traded) }\end{array}$

B. Parameters of Stock Effect Function in Oil and Gas Industry

$\begin{array}{lcccc}\text { Parameter: } & \mathrm{Z}_{0} & \overline{\mathrm{Z}} & \varepsilon_{1} & \varepsilon_{2} \\ \text { Value: } & 0 & 450 & 1.27 & 2.0\end{array}$

Note: This function is parameterized so that $\gamma_{f}$ approaches 0 as $Z$ approaches $\bar{Z}$ (see equation (8)). The value of $\bar{Z}$ is 450 billion barrels (about 100 times the 1990 production of oil and gas, where gas is measured in barrelequivalents.) $\bar{Z}$ is based on estimates from Masters et al. (1987). Investment in new oil and gas capital ceases to be profitable before reserves are depleted: the values of $\varepsilon_{1}$ and $\varepsilon_{2}$ imply that, in the baseline scenario, oil and gas investment becomes zero in the year 2031.

C. Utility Function Parameters

$\begin{array}{lcccc}\text { Parameter: } & \omega & \sigma & v & \eta \\ \text { Value: } & 0.007 & 0.5 & 0.69 & 0.84\end{array}$

